\title{
Harnessing endogenous pathways and metabolites to treat or prevent neurodegenerative disease
}

\author{
Todd E Golde*, Kevin Felsenstein, Paramita Chakrabarty, Andy Li, Brenda Moore, Jung Joo In, Pedor Cruz, \\ Ashely Price, David Borchelt, Christopher Janus, Carolina Cebballos-Diaz, Awilda Rosario
}

From Molecular Neurodegeneration: Basic biology and disease pathways

Cannes, France. 10-12 September 2013

As the field moves towards earlier interventions in preclinical stages of $\mathrm{AD}$ or even envisions true primary prevention strategies, the therapeutic strategies employed must be "safe enough". Whether any current therapeutic (e.g., $\beta$-secretase inhibitors, $\gamma$-secretase modulators (GSM) or anti-A $\beta$ immunotherapies) being tested for disease modification is sufficiently safe is not known. In order to try and identify "safe enough" therapeutics, we have been evaluating whether endogenous regulators of $A \beta$ can be harnessed as therapeutics. We have identified a cholesterol metabolite, cholestenoic acid (CA), as potent GSM, and have genetic data from mice that are consistent with a role for $C A$ in regulating $A \beta 42$ levels in the brain. We will discuss our ongoing studies exploring how we might utilize CA or the CA metabolic pathway to safely lower A $\beta 42$ levels. In addition, we have been evaluating how we can use soluble forms of endogenous innate immune receptors to alter $A \beta$ deposition and modulate neuroinflammation in mouse models of AD. We have also been exploring the utility of such strategy in other neurodegenerative models. Effects of soluble toll-like receptors and soluble TREM2 will be presented. Our current data establish that soluble TLR4 and 5 both dramatically inhibit $\mathrm{A} \beta$ deposition but that soluble TLR2 and 6 do not. We also have data that suggest the utility of these soluble receptors in $\alpha$-synucleinopathies. By using endogenous metabolites and receptors, we hope that the likelihood of

Center for Translational Research in Neurodegenerative Disease, Department of Neuroscience, McKnight Brain Institute, College of Medicine, University of Florida, Gainesville, FL, USA adverse toxicities will be diminished and that these or endogenous factors can be safely developed for prophylactic or early intervention in $\mathrm{AD}$ and perhaps other neurodegenerative disorders.

Published: 13 September 2013

doi:10.1186/1750-1326-8-S1-036

Cite this article as: Golde et al:: Harnessing endogenous pathways and metabolites to treat or prevent neurodegenerative disease. Molecular Neurodegeneration 2013 8(Suppl 1):036.
Submit your next manuscript to BioMed Central and take full advantage of:

- Convenient online submission

- Thorough peer review

- No space constraints or color figure charges

- Immediate publication on acceptance

- Inclusion in PubMed, CAS, Scopus and Google Scholar

- Research which is freely available for redistribution
() Biomed Central 